\title{
ANALGESIC EFFECT OF TRAMADOL IS NOT ALTERED BY POSTOPERATIVE SYSTEMIC INFLAMMATION AFTER MAJOR ABDOMINAL SURGERY
}

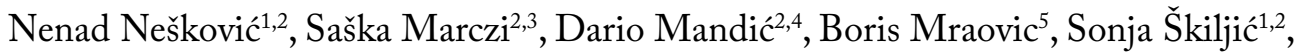 \\ Gordana Kristek ${ }^{1,2}$,Hrvoje Vinković ${ }^{1,2}$ and Slavica Kvolik ${ }^{1,2}$
}

${ }^{1}$ Osijek University Hospital Centre, Department of Anesthesiology, Resuscitation and Intensive Medicine, Osijek, Croatia;

${ }^{2}$ Faculty of Medicine, Josip Juraj Strossmayer University of Osijek, Osijek, Croatia;

${ }^{3}$ Osijek University Hospital Centre, Department of Transfusion Medicine,

Laboratory of Molecular and HLA Diagnostics, Osijek, Croatia;

${ }^{4}$ Osijek University Hospital Centre, Department of Clinical and Laboratory Diagnostics, Osijek, Croatia; ${ }^{5}$ University of Missouri, Department of Anesthesiology and Perioperative Medicine, School of Medicine, Columbia, USA

\begin{abstract}
SUMMARY - Tramadol is a commonly used analgesic in intensive care units (ICUs) for acute postoperative pain. Conversion of tramadol into active metabolites may be impaired in inflammatory states. Catechol-O-methyltransferase may influence pain. The aim of the study was to examine differences in the analgesic effect of tramadol between ICU patients with and without signs of systemic inflammation. Forty-three patients were admitted to ICU after a major abdominal surgery. The patients received a dose of $100 \mathrm{mg}$ of tramadol intravenously every 6 hours during the first 24 hours after surgical procedure. Pain scores were measured by the Numeric Rating Scale before and 30 minutes after tramadol administration in awake patients. Systemic inflammation was considered when at least two of the following postoperative parameters were present in the first 24 hours of ICU admission: fever or hypothermia, tachycardia, $\mathrm{pCO}_{2}<4.3 \mathrm{kPa}$, white blood cells $>12000 / \mathrm{mm}^{3}$ or $<4000 / \mathrm{mm}^{3}$, or preoperative value of C-reactive protein $(\mathrm{CRP})>50 \mathrm{mg} / \mathrm{L}$ or/and procalcitonin $(\mathrm{PCT})$ $>0.5 \mathrm{mg} / \mathrm{L}$. Catechol-O-methyltransferase was analyzed postoperatively. Fifteen (34.8\%) patients met the criteria for systemic inflammation. Tramadol was proven to be an effective analgesic for the treatment of postoperative pain regardless of the presence of systemic inflammation $(\mathrm{p}<0.05)$. Lower perception of pain before tramadol application was observed in patients with systemic inflammation, but the difference was not significant. A negative correlation was observed between the preoperative values of CRP and PCT and the analgesic effect of tramadol assessed at the second measurement point $(r=-0.358, p=0.03$, and $r=-0.364, p=0.02$, respectively). Catechol-O-methyltransferase variants were not in correlation with pain and opioid consumption. Based on our findings, tramadol is effective in lowering pain scores after major abdominal surgery irrespective of the presence of systemic inflammation.
\end{abstract}

Key words: Analgesia; Critical care; Systemic inflammatory response; Catechol-O-methyltransferase; Tramadol

\section{Introduction}

Tramadol is an opioid analgesic commonly used in intensive care units (ICUs) for the treatment of acute postoperative pain because of its low potential for re-

Correspondence to: Nenad Nešković, $M D, P h D$, Osijek University Hospital Centre, Josipa Huttlera 4, HR-31000 Osijek, Croatia E-mail: nneskov@gmail.com

Received June 2, 2020, accepted September 29, 2020 
spiratory depression and constipation compared to other opioids. In addition to its effects on $\mu$-opioid receptors, unlike other opioids, it also acts by neuromodulations of pain on the descending inhibitory pathway inhibiting the reuptake of serotonin and noradrenaline ${ }^{1,2}$. Cytochrome P450 metabolizes tramadol into 11 demethylated metabolites of which the most important are $O$-demethyltramadol (M1) and $N$-demethyltramadol (M2). The analgesic effect of tramadol is primarily determined by the concentration of M1 metabolite, the synthesis of which depends on the CYP2D6 isoenzyme of cytochrome $\mathrm{P} 450^{1,3}$. In relation to CYP2D6 polymorphism, there are poor, intermediate, extensive, and ultra-fast metabolizers. Most of the population are extensive metabolizers (70\%$80 \%)$, whereas poor, intermediate and ultrafast metabolizers account for approximately 5\%-10\%, 3\%-5\% and $10 \%-17 \%$, respectively ${ }^{4} . \mathrm{N}$-demethylation, catalyzed by the CYP3A4 and CYP2B6 isoenzymes, results in inactive $N$-demethyltramadol (M2) ${ }^{5,6}$. CYP2D6 is a non-inducible enzyme but numerous physiologic and pathologic processes affect its activity. Infections and inflammation generally reduce the liver capacity to metabolize drugs ${ }^{7}$.

Surgical trauma causes somatic and visceral pain leading to changes in the endocrine and metabolic systems $^{8}$. Tissue trauma, length of procedure, anesthesia, preoperative fasting, emergency surgery, and many other factors contribute to the development of systemic inflammation ${ }^{9,10}$, and in such a pathophysiological environment it is difficult to predict the analgesic effect of tramadol. Systemic inflammatory response syndrome (SIRS) is common after major surgeries in patients admitted to ICUs. SIRS criteria were met at least once in more than $40 \%$ of patients during their ward hospitalization, and as many as $35 \%$ of acutely hospitalized medical patients had SIRS on hospital admission $^{11,12}$. Proinflammatory cytokines (i.e. interleukin 6 (IL-6)) decrease CYP3A4 and CYP2D6 activity ${ }^{13,14}$ and might affect the analgesic effect of tramadol. Moreover, the proinflammatory cytokines activate nitric oxide synthase (NOS), resulting in the release of nitric oxide (NO) and dimethylarginines ${ }^{15}$. These metabolites contribute to oxidative stress and thromboinflammation ${ }^{16}$. NO has the potential to inhibit CYP2D6 gene transcription ${ }^{17}$. IL-6 decreases both CYP3A4 and CYP2D6 expression. IL-6 concentration correlates well with serum concentration of $\mathrm{C}$-reactive protein (CRP) and procalcitonin (PCT) as common inflammatory markers ${ }^{18}$. In addition to the aforementioned enzymes, catecholamine-O-methyltransferase (COMT) variants may be associated with pain perception and postoperative opioid consumption. GG (Val/Val) genotype has high enzymatic activity, GA (Val/Met) genotype has moderate enzymatic activity, and AA (Met/Met) genotype produces defective enzymes. The carriers of COMT AA genotype had the lowest opioid consumption compared to GG and GA patients ${ }^{19}$.

The objective of this study was to compare analgesic effect of tramadol in patients admitted to ICU after major abdominal surgery with and without perioperative signs of systemic inflammation. We hypothesized that patients who developed systemic inflammation would have reduced analgesic effects of tramadol during the first 24 hours after admission to ICU.

\section{Patients and Methods}

This prospective observational study of the postoperative pain treatment in patients admitted to ICU after major abdominal surgery (trial registration number NCT04330157) was approved by the Ethics Committee of the Osijek University Hospital Centre (2158-61-07-19-02). All patients included in the study signed the informed consent form.

Patients undergoing laparotomy for major abdominal surgeries with organ resections were eligible for the study, irrespective of whether they had an emergency or elective surgery. Patients with known allergies to tramadol or altered mental status who were unable to understand study protocol and pain assessment scores, those younger than 18 and older than 90 years, and patients undergoing laparoscopic surgery were not included. Between January 2019 and January 2020, a total of 50 patients were enrolled, but only 43 patients met all the criteria for analysis, as shown in Figure 1.

Blood samples were collected before surgery for analysis of white blood cell count (WBC), serum albumin, creatinine, CRP, PCT, lactate level, and arterial blood gases. Systemic inflammation was considered when at least two of the following major criteria were met in the postoperative period: temperature $>38^{\circ} \mathrm{C}$ or $<36{ }^{\circ} \mathrm{C}$, heart rate $>90$ beats/minute, $\mathrm{pCO}_{2}$ in arterial blood $<4.3 \mathrm{kPa}$, and $\mathrm{WBC}>12,000 / \mathrm{mm}^{3}$ or $<4,000 / \mathrm{mm}^{3}$. Preoperative CRP $>50 \mathrm{mg} / \mathrm{L}$ and/or 


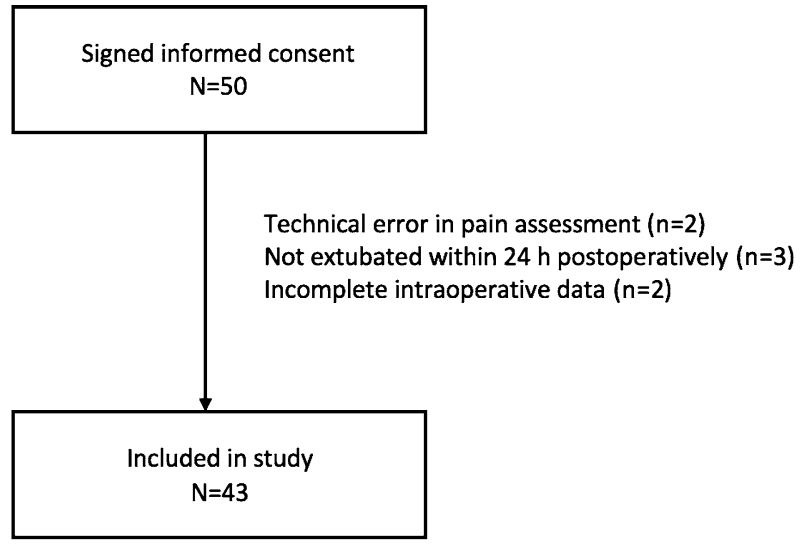

Fig. 1. Flow diagram of patient inclusion.

PCT $>0.5 \mathrm{mg} / \mathrm{L}$ were also considered as systemic inflammation independently of the previous criteria ${ }^{20}$. If patients had borderline levels of inflammatory markers and without meeting major criteria, then lactate levels above $2 \mathrm{mmol} / \mathrm{L}$ in the first 24 hours were considered as a sign of systemic inflammation ${ }^{21}$.

\section{Intraoperative procedures}

General anesthesia was induced with propofol and rocuronium, whereas etomidate and succinylcholine were used as induction anesthetics during the emergency procedure and in hemodynamically unstable patients. Balanced anesthesia was maintained with sevoflurane with a mixture of oxygen/air, rocuronium, and additional doses of fentanyl or sufentanil, depending on the intraoperative blood pressure, heart rate, hemodynamic stability, type and length of the procedure. Heart rate, 3-channel electrocardiography, invasive intra-arterial pressure, temperature, and diuresis were monitored intraoperatively. Hypotensive patients $(\leq 70$ $\mathrm{mm} \mathrm{Hg}$ ) received a bolus or continuous infusion of norepinephrine. A bolus dose of morphine was given 30 minutes before the completion of surgery. Sedatives were not administered. All intraoperative administrations of opioids were recorded and analyzed. After the procedure, patients were admitted to ICU and their vital parameters were monitored, as well as mechanical ventilation until extubation.

\section{Postoperative analgesia and pain assessment}

All patients received $100 \mathrm{mg}$ of tramadol intravenously (i.v.) during the first hour of ICU admission and thereafter at 6-hour intervals. Paracetamol $1 \mathrm{~g}$ was administered every 6 hours as a supplemental analgesic, between tramadol injections. Pain was assessed in awake, extubated patients by verbal Numeric Rating Scale (NRS) ${ }^{22}$. Pain was assessed at the following time points: 1) immediately after ICU admission: 2) after 6 hours; 3) after 12 hours; 4) after 18 hours; and 5) after 24 hours, both before tramadol administration (time point $\mathrm{A}$ ) and 30 minutes after its administration (time point $\mathrm{B}$ ), i.e. NRS2-B is the numeric rating score 30 minutes after the second dose of tramadol. Analgesia was considered adequate if NRS was $\leq 3$. Additional morphine i.v. bolus $(2 \mathrm{mg})$ was administered if analgesia was assessed as inadequate and/or on patient request. Total morphine consumption was recorded.

\section{COMT rs 4680 genotyping}

Genomic DNA was extracted from $200 \mathrm{~mL}$ of EDTA anticoagulated whole blood samples using the High Pure PCR Template Preparation Kit (Roche Diagnostics, Mannheim, Germany), following the instructions of the manufacturer. The COMT rs4680 polymorphism was genotyped using the LightSNiP Kit (TIB Molbiol, Berlin, Germany) and FastStart DNA Master HybProbe (Roche Diagnostics, Mannheim, Germany). Amplification by real-time PCR and subsequent analysis of melting curve were performed on the LightCycler 480 II (Roche Diagnostics, Mannheim, Germany), according to the manufacturer's instructions.

\section{Statistical analysis}

Statistical analysis was performed using MedCalc Statistical Software package version 19.1.7 (MedCalc Software Ltd., Ostend, Belgium) and IBM SPSS (SPSS Statistics for Windows, Version 17.0. SPSS Inc., Chicago, USA). Categorical data were expressed as absolute and relative frequencies. Numerical data were described with median and limits of the interquartile range. The normality of distribution of numerical variables was tested by Shapiro-Wilk test. Differences between two independent groups were tested with Mann-Whitney U test and between two dependent groups with Wilcoxon test. Independent sample Kruskal-Wallis test was used for comparison of three groups. The Spearman's rho test was used to determine associations between non-normally distributed variables. All $\mathrm{p}$ values were calculated two-sided and the level of significance was set at $\alpha=0.05$. 
Table 1. Demographic characteristics of study patients and type of surgical procedure

\begin{tabular}{|l|l|}
\hline Sex $($ male/female) & $28(65.1 \%) / 15(34.9 \%)$ \\
Age (years) & $67(59-73)$ \\
BMI $\left(\mathrm{kg} / \mathrm{m}^{2}\right)$ & $26.1(22.8-28.0)$ \\
Smoking status & $18(41.9 \%)$ \\
ASA status & $10(23.3 \%) / 26(60.5 \%) / 7(16.3 \%)$ \\
II/III/IV & \\
$\begin{array}{l}\text { Surgical procedure: } \\
\text { colorectal }\end{array}$ & $24(55.8 \%)$ \\
gastric & $6(14.0 \%)$ \\
small intestine & $2(4.7 \%)$ \\
liver & $5(11.6 \%)$ \\
pancreas & $3(7.0 \%)$ \\
multiple resections & $3(7.0 \%)$ \\
\hline
\end{tabular}

For categorical data, total number of patients and ratio (\%), and for continuous data median and interquartile range were used; $\mathrm{BMI}=$ body mass index; ASA = American Society of Anesthesiologists

\section{Results}

The type of surgical procedure and demographic characteristics of 43 patients are shown in Table 1 . Thirty-four (79.1\%) patients underwent elective surgery, nine (20.9\%) patients emergency surgery, and 36 (83.7\%) patients cancer surgery. The median duration of surgery was 135 (120-180) minutes. Urgent procedures lasted shorter than the elective ones (120 (75144) minutes vs. 150 (120-180) minutes; $\mathrm{p}=0.009)$.

The criteria for systemic inflammation were met in $15(34.8 \%)$ patients and they underwent emergency surgery more often $(7 / 15 ; 47 \%)$ than patients not meeting the criteria for systemic inflammation $(2 / 28$; $7 \%)$. Comparison of patients with and without signs of systemic inflammation is illustrated in Table 2.

There were no differences in patient demographic characteristics or in preoperative red blood cell, platelet, bilirubin, serum urea and creatinine levels between patients with and without systemic inflammation. The group with systemic inflammatory response had sig-

Table 2. Comparison of patients with and without systemic inflammation

\begin{tabular}{|l|l|l|l|}
\hline & \multicolumn{2}{|c|}{ Systemic inflammation } & \\
\hline & Yes $(\mathrm{N}=15)$ & No $(\mathrm{N}=28)$ & $\mathrm{p}^{*}$ \\
\hline Male/female & $10(67) / 5(33)$ & $18(64) / 10(36)$ & 0.57 \\
Age (years) & $69(57-76)$ & $66(59.5-71.7)$ & 0.51 \\
Body mass index $\left(\mathrm{kg} / \mathrm{m}^{2}\right)$ & $24.3(20.7-27.4)$ & $26.5(23.3-29.2)$ & 0.13 \\
Procalcitonin (mg/L) & $0.38(0.08-7.63)$ & $0.06(0.04-0.1)$ & $<0.001$ \\
C-reactive protein (mg/L) & $59(2.5-211.8)$ & $7(2.2-17.1)$ & 0.01 \\
COMT (GA + GG/AA) & $7 / 7$ & $24 / 4$ & 0.016 \\
Lactate (mmol/L) & $0.85(0.5-1.5)$ & $0.7(0.5-0.9)$ & 0.10 \\
Albumin (g/L) & $26.3(23.0-30.7)$ & $32.1(29.0-35.2)$ & 0.007 \\
Creatinine (mmol/L) & $75(54-122)$ & $65(54-82.2)$ & 0.36 \\
Emergency surgery & $7(46.6)$ & $2(7.1)$ & 0.005 \\
Duration of surgery (min) & $150(120-180)$ & $135(120-180)$ & 0.73 \\
Intraoperative opioids ${ }^{1}(\mathrm{mg})$ & $55(45-75)$ & $75(61.2-93)$ & 0.07 \\
Intraoperative norepinephrine $^{2}$ & $6(40)$ & $6(21.4)$ & 0.19 \\
Postoperative morphine $(\mathrm{mg})$ & $2(0-8)$ & $4(2-10)$ & 0.15 \\
PONV & $3(20)$ & $13(46.4)$ & 0.11 \\
\hline
\end{tabular}

For categorical data, total number of patients and rate (\%), and for continuous data median and interquartile range were used. $\mathrm{PONV}$ = postoperative nausea and vomiting; COMT = catecholamine-O-methyltransferase: GG (Val/Val) genotype, GA (Val/Met), and AA (Met/Met) genotype; *Mann-Whitney U test for continuous and Fisher exact test for categorical data; ${ }^{1}$ expressed as milligrams of morphine equivalent; ${ }^{2}$ number of patients who received norepinephrine intraoperatively 


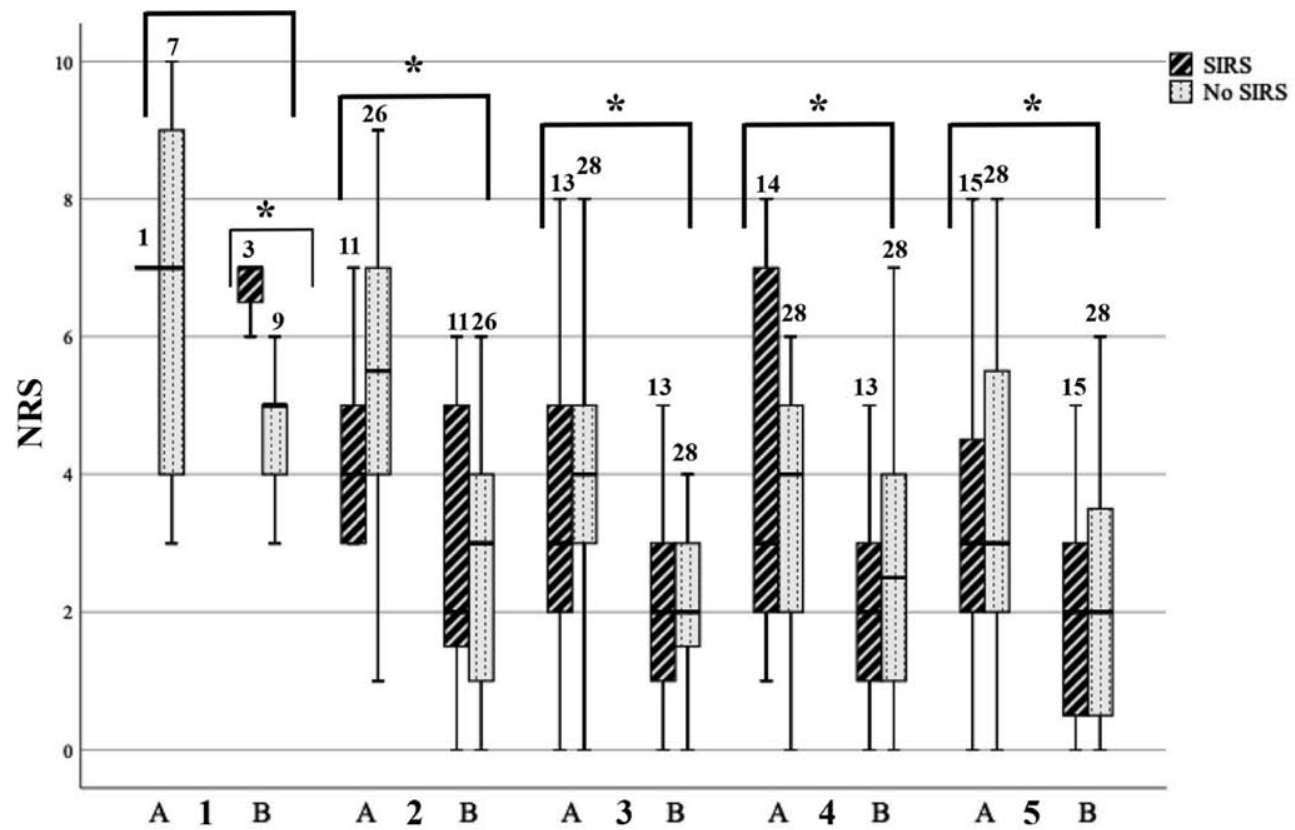

Fig. 2. Analgesic effect of tramadol in patients with or without systemic inflammation at 4 measurement points.

1-5 are pain assessment points, $A$ before and $B$ after application of $100 \mathrm{mg}$ tramadol i.v.; number of patients is written above the boxplot; NRS = Numeric Rating Scale; SIRS = systemic inflammatory response; ${ }^{*} \mathrm{p}<0.05$ (upper cluster: Wilcoxon test between A and B NRS. At first assessment point, only patients without SIRS were analyzed; lower cluster: Mann-Whitney U test between NRS 1 B with respect to SIRS).

nificantly lower preoperative serum albumin levels, and higher CRP and PCT levels (Table 2).

\section{Postoperative pain and opioid consumption}

Total intraoperative opioid consumption was lower in patients with systemic inflammation, but the difference was not statistically significant (Table 2). Postoperative morphine consumption was 2 and $4 \mathrm{mg}$ in $\mathrm{pa}^{-}$ tients with and without systemic inflammation, respectively $(p=0.238)$. Less patients in the group with systemic inflammation reported postoperative nausea and vomiting and were administered antiemetics, although differences were not significant.

The rates of patient tracheal extubation cumulatively were 8 (18.6\%), 37 (86\%), 41 (95.3\%) and 42 $(97.6 \%)$ at the time of the $1^{\text {st }}, 2^{\text {nd }}, 3^{\text {rd }}$ and $4^{\text {th }}$ pain assessment points. By the end of the study and at fifth pain assessment, all included patients were awake and extubated. At the first pain assessment point before (NRS1-A) and after tramadol application (NRS1-B), only one and three patients with SIRS were extubated, respectively. Therefore, the analgesic effect of tramadol at the first assessment point in patients with SIRS could not be calculated. In patients without SIRS, tramadol was ineffective in reducing pain at the first measurement. Median NRS value before tramadol was 7 (3-10) and after tramadol injection it was 5 (3.5-5.5) ( $p=0.09$, Wilcoxon test). After tramadol application, patients with inflammatory response had a significantly higher NRS score at first measurement point ( $\mathrm{p}=0.02$, Mann-Whitney U test).

At the following measurement points, tramadol administration reduced NRS significantly in both patient groups with no statistically significant betweengroup differences. Median NRS values were lower before tramadol application at almost all measurement points in patients with inflammatory response, although the difference was not significant. NRS values at the five measurement points are shown in Figure 2.

Pain relief at 6 hours of ICU admission (presented as difference between NRS scores before and after tramadol administration) was negatively correlated with preoperative CRP and PCT levels ( $r=-0.358 ; \mathrm{p}=0.03$ and $r=-0.364 ; p=0.02$, respectively). We also analyzed 
pain scores in patients who received intraoperative fentanyl or sufentanil. The analgesic effect of tramadol at all time points was not associated with the type of opioid administered intraoperatively.

\section{COMTrs4680 genotype, opioid consumption and postoperative pain}

COMT rs4680 was analyzed in a total of $42 \mathrm{pa}^{-}$ tients; 21 patients had GA genotype, 12 had AA genotype, while GG genotype was recorded in nine patients. Intraoperative consumption of opiates expressed as morphine equivalent was 85 (47.5-100) $\mathrm{mg}, 70$ (5594.5) $\mathrm{mg}$ and 68 (53.5-79.5) $\mathrm{mg}$ in GG, GA and AA genotypes, respectively. There was no statistically significant difference in intraoperative opiate consumption according to COMT genotype $(\mathrm{p}=0.870)$. There was no difference in pain at any measurement point or in postoperative opioid consumption among different COMT rs4680 genotypes either. Systemic inflammation was more common in GA and GG genotypes as compared to AA genotype.

\section{Discussion}

Pain is an important stressor in ICU and a strong contributing factor in the development of delirium and ICU-related post-traumatic stress disorder. Thus, assessment of pain and adequacy of analgesia in ICU are very important ${ }^{23}$. In our cohort, patients were not divided into septic and non-septic but according to the clinical criteria for systemic inflammation, which is common after major abdominal surgery. Considering that the cytochrome enzyme CYP2D6 activity was equally altered in both patient groups, the analgesic effect of tramadol was not found to be different after major abdominal surgery irrespective of whether the patient developed postoperative systemic inflammation or not.

The perception of pain before the administration of tramadol in patients with systemic inflammation was lower, although proinflammatory cytokines, peritonitis, and more severe tissue trauma were expected to result in greater production of nociceptive neurotransmitters due to neuro-immune interaction ${ }^{24}$. This may be partly explained by brain dysfunction that occurs in systemic inflammation ${ }^{25}$. McGrane et al. showed that elevated CRP and PCT values correlated with brain dysfunction independently of the diagnosis of sepsis $^{26}$. Moreover, low mean arterial pressure and greater use of vasopressors in systemic inflammation may be responsible for altered cerebral autoregulation and mental impairment, and thus for the reduced pain experience in these patients ${ }^{27,28}$.

In the study conducted by Crippa et al., impaired cerebral autoregulation was associated with brain dysfunction. The authors concluded that both a history of vascular disease and cerebral hypoxia could contribute to the development of brain dysfunction ${ }^{29}$. In our $\mathrm{pa}^{-}$ tients, altered mental status may have underlain the observers' inability to assess pain immediately after admission to ICU and explain the lower pain scores at all subsequent measurements in patients with systemic inflammation.

In the meta-analysis by $\mathrm{Hu}$ et al., postoperative pain was found to be higher in COMT rs4680 GG and GA variants, and was in correlation with postoperative opioid consumption ${ }^{19}$. Our study did not confirm correlation of COMT variants with any of outcomes. This may be due to the small sample, but also due to the heterogeneous group of emergency and elective surgical patients. The only difference among the genotypes was the higher incidence of systemic inflammation, which was observed in 7 of 11 carriers of the AA genotype.

Although we found tramadol to be equally effective for pain relief in patients with and without the criteria for systemic inflammation, a weaker analgesic effect at the $2^{\text {nd }}$ measurement point was recorded in the subset of patients presented with higher preoperative $\mathrm{CRP}$ and PCT values. Also, NRS value after first tramadol application was higher in patients with systemic inflammation. A potential explanation of these difference may be decreased activity of the CYP2D6 enzyme in systemic inflammatory conditions and decreased synthesis of the active M1 metabolite, but the enzyme activity was not determined in this cohort. The limitations of our study were small sample size, heterogeneity of patients regarding ASA status, and heterogeneity of the type of surgery. Studies have shown the state of systemic inflammation to be characterized with a decreased expression of drug transporters on hepatocytes and peripheral tissues ${ }^{30-32}$. This may lead to a higher concentration of tramadol and its metabolites and be the reason for the good analgesic effect of tramadol despite cytokine-related decreases in the CYP2D6 enzyme activity. 
In conclusion, this study confirmed that tramadol provided effective pain relief in all patients after major abdominal surgery. The negative correlation between the values of inflammatory parameters and the analgesic effect of tramadol at one measurement point certainly requires a larger study with a more homogeneous sample of patients to determine the exact analgesic effect of tramadol in systemic inflammatory conditions, as well as on pain perception in these patients.

\section{Acknowledgments}

This study was funded by institutional support from the Osijek University Hospital Centre and VIF2016-MEFOS-15, VIF 2017-MEFOS-16, and IP18-2020 projects supported by the Faculty of Medicine, Josip Juraj Strossmayer University of Osijek, Osijek, Croatia.

\section{References}

1. Grond S, Sablotzki A. Clinical pharmacology of tramadol. Clin Pharmacokinet. 2004;43(13):879-923. DOI: 10.2165/00003 088-200443130-00004

2. Barakat A. Revisiting tramadol: a multi-modal agent for pain management. CNS Drugs. 2019;33(5):481-501.DOI: 10.1007 /s40263-019-00623-5

3. Wu WN, McKown LA, Liao S. Metabolism of the analgesic drug ULTRAM (tramadol hydrochloride) in humans: API-MS and MS/MS characterization of metabolites. Xenobiotica. 2002;32(5):411-25. DOI: 10.1080/00498250110113230

4. Alván G, Bechtel P, Iselius L, Gundert-Remy U. Hydroxylation polymorphisms of debrisoquine and mephenytoin in $\mathrm{Eu}-$ ropean populations. Eur J Clin Pharmacol. 1990;39(6):533-7. DOI: $10.1007 / \mathrm{bf} 00316090$

5. Gillen C, Haurand M, Kobelt DJ, Wnendt S. Affinity, potency and efficacy of tramadol and its metabolites at the cloned human mu-opioid receptor. Naunyn Schmiedebergs Arch Pharmacol. 2000;362(2):116-21. DOI: 10.1007/s002100000266

6. Miotto K, Cho AK, Khalil MA, Blanco K, Sasaki JD, Rawson R. Trends in tramadol: pharmacology, metabolism, and misuse. Anesth Analg. 2017;124(1):44-51. DOI: 10.1213/ANE.000 0000000001683

7. Kluge M, Tacke F. Liver impairment in critical illness and sepsis: the dawn of new biomarkers? Ann Transl Med. 2019; 7(Suppl 8):S258. DOI: 10.21037/atm.2019.12.79

8. Novak-Jankovič V, Markovič-Božič J. Regional anaesthesia in thoracic and abdominal surgery. Acta Clin Croat. 2019;58 (Suppl 1):96-100. DOI: 10.20471/acc.2019.58.s1.14

9. Becher RD, Hoth JJ, Miller PR, Meredith JW, Chang MC. Systemic inflammation worsens outcomes in emergency surgi- cal patients. J Trauma Acute Care Surg. 2012;72(5):1140-9. DOI: 10.1097/TA.0b013e3182516a97

10. Rizvanović N, Nesek Adam V, Čaušević S, Dervišević S, Delibegović S. A randomised controlled study of preoperative oral carbohydrate loading versus fasting in patients undergoing colorectal surgery. Int J Colorectal Dis. 2019;34(9):1551-61. DOI: $10.1007 / \mathrm{s} 00384-019-03349-4$

11. Churpek MM, Zadravecz FJ, Winslow C, Howell MD, Edelson DP. Incidence and prognostic value of the systemic inflammatory response syndrome and organ dysfunctions in ward patients. Am J Respir Crit Care Med. 2015;192(8):958-64. DOI: $10.1164 / \mathrm{rccm} .201502-0275$ OC

12. Comstedt P, Storgaard M, Lassen AT. The systemic inflammatory response syndrome (SIRS) in acutely hospitalised medical patients: a cohort study. Scand J Trauma Resusc Emerg Med. 2009;17:67. DOI: 10.1186/1757-7241-17-67

13. He ZX, Chen XW, Zhou ZW, Zhou SF. Impact of physiological, pathological and environmental factors on the expression and activity of human cytochrome P450 2D6 and implications in precision medicine. Drug Metab Rev. 2015;47(4):470-519. DOI: $10.3109 / 03602532.2015 .1101131$

14. Martínez-Jiménez CP, Jover R, Donato MT, Castell JV, Gómez-Lechón MJ. Transcriptional regulation and expression of CYP3A4 in hepatocytes. Curr Drug Metab. 2007;8(2):185-94. DOI: $10.2174 / 138920007779815986$

15. Blackwell S, O’Reilly DSJ, Reid D, Talwar D. Plasma dimethylarginines during the acute inflammatory response. Eur J Clin Invest. 2011;41(6):635-41. DOI: 10.1111/j.1365-2362.2010. 02451.x

16. Molnar T, Pusch G, Nagy L, Keki S, Berki T, Illes Z. Correlation of the L-arginine pathway with thrombo-inflammation may contribute to the outcome of acute ischemic stroke. J Stroke Cerebrovasc Dis. 2016;25(8):2055-60. DOI: 10.1016/j. jstrokecerebrovasdis.2016.05.018

17. Carlson TJ, Billings RE. Role of nitric oxide in the cytokinemediated regulation of cytochrome P-450. Mol Pharmacol. 1996;49(5):796-801.

18. Mallick P,Taneja G, Moorthy B, Ghose R. Regulation of drugmetabolizing enzymes in infectious and inflammatory disease: implications for biologics-small molecule drug interactions. Expert Opin Drug Metab Toxicol. 2017;13(6):605-16. DOI: 10.1080/17425255.2017.1292251

19. Hu B, Zhang X, Xu G, Zhang Q, Qian P, Liu S, Zhu J, Shen R. Association between COMT polymorphism Val158Met and opioid consumption in patients with postoperative pain: a meta-analysis. Neurosignals. 2018;26(1):11-21. DOI: 10.1159 /000487038

20. Castelli GP, Pognani C, Meisner M, Stuani A, Bellomi D, Sgarbi L. Procalcitonin and C-reactive protein during systemic inflammatory response syndrome, sepsis and organ dysfunction. Crit Care. 2004;8(4):234-42. DOI: 10.1186/cc2877

21. Cicarelli DD, Veiera JE, Bensenor FEM. Lactate as a predictor of mortality and multiple organ failure in patients with the sys- 
temic inflammatory response syndrome. Rev Bras Anestesiol. 2007;57(6):630-8. DOI: 10.1590/S0034-70942007000600005

22. Gerbershagen HJ, Rothaug J, Kalkman CJ, Meissner W. Determination of moderate-to-severe postoperative pain on the numeric rating scale: a cut-off point analysis applying four different methods. Br J Anaesth. 2011;107(4):619-26. DOI: 10.1093/bja/aer195

23. Marra A, Pandharipande PP, Patel MB. Intensive care unit delirium and intensive care unit-related posttraumatic stress disorder. Surg Clin North Am. 2017;97(6):1215-35. DOI: 10.1016/j.suc.2017.07.008

24. Pinho-Ribeiro FA, Verri WA Jr, Chiu IM. Nociceptor sensory neuron-immune interactions in pain and inflammation. Trends Immunol. 2017;38(1):5-19. DOI: 10.1016/j.it.2016.10.001

25. Sonneville R, Verdonk F, Rauturier C, Klein IF, Wolff M, Annane $\mathrm{D}$, et al. Understanding brain dysfunction in sepsis. Ann Intensive Care. 2013;3(1):15. DOI: 10.1186/2110-5820-3-15

26. McGrane S, Girard TD, Thompson JL, Shintani AK, Woodworth A, Ely EW, et al. Procalcitonin and C-reactive protein levels at admission as predictors of duration of acute brain dysfunction in critically ill patients. Crit Care. 2011;15(2):R78. DOI: $10.1186 / \mathrm{cc} 10070$

27. Berg RM, Plovsing RR, Bailey DM, Holstein-Rathlou NH, Møller K. The dynamic cerebral autoregulatory adaptive re- sponse to noradrenaline is attenuated during systemic inflammation in humans. Clin Exp Pharmacol Physiol. 2015;42 (7):740-6. DOI: 10.1111/1440-1681.12421

28. Skelly DT, Griffin EW, Murray CL, et al. Acute transient cognitive dysfunction and acute brain injury induced by systemic inflammation occur by dissociable IL-1-dependent mechanisms. Mol Psychiatry. 2019;24(10):1533-48. DOI: 10.1038/ s41380-018-0075-8

29. Crippa IA, Subirà C, Vincent JL, Fernandez RF, Hernandez $\mathrm{SC}$, Cavicchi FZ, et al. Impaired cerebral autoregulation is associated with brain dysfunction in patients with sepsis. Crit Care. 2018 Dec 4;22(1):327. DOI: 10.1186/s13054-0182258-8

30. Cressman AM, Petrovic V, Piquette-Miller M. Inflammationmediated changes in drug transporter expression/activity: implications for therapeutic drug response. Expert Rev Clin Pharmacol. 2012;5(1):69-89. DOI: 10.1586/ecp.11.66

31. Petrovic V, Teng S, Piquette-Miller M. Regulation of drug transporters during infection and inflammation. Mol Interv. 2007;7(2):99-111. DOI: 10.1124/mi.7.2.10

32. Fardel O, Le Vée M. Regulation of human hepatic drug transporter expression by pro-inflammatory cytokines. Expert Opin Drug Metab Toxicol. 2009;5(12):1469-81. DOI: 10.1517/17 425250903304056

Sažetak

\section{POSLIJEOPERACIJSKA SUSTAVNA UPALA NAKON VELIKE ABDOMINALNE OPERACIJE NE MIJENJA ANALGETSKI UČINAK TRAMADOLA}

\section{N. Nešković, S. Marczi, D. Mandić, B. Mraovic, S. Škiljič, G. Kristek, H. Vinkovič i S. Kvolik}

Tramadol je analgetik koji se često rabi za poslijeoperacijsku bol u jedinicama intenzivnog liječenja (JIL). Njegova konverzija u aktivni metabolit zbiva se putem enzima CYP2D6, funkcija kojega je smanjena u stanjima sustavne upale. Na doživljaj boli mogu utjecati i varijante katehol-O-metiltransferaze. Cilj istraživanja bio je ispitati razlike u analgetskom učinku tramadola kod bolesnika ovisno o razvoju sustavne upale. Četrdesettroje bolesnika primljena su u JIL nakon velikih abdominalnih operacija te su intravenski primili $100 \mathrm{mg}$ tramadola svakih 6 sati tijekom 24 sata. Procjena boli putem numeričke ocjenske ljestvice (NRS) rađena je prije i 30 minuta nakon primjene tramadola. Smatralo se da bolesnici imaju sustavnu upalu ako su u prva 24 sata poslijeoperacijski imali barem dva od sljedećih kriterija: vrućica ili hipotermija, tahikardija, $\mathrm{pCO}_{2}$ $<4,3 \mathrm{kPa}$, leukociti $>12000 / \mathrm{mm}^{3}$ ili $<4000 / \mathrm{mm}^{3}$ ili prijeoperacijski C-reaktivni protein $(\mathrm{CRP})>50 \mathrm{mg} / \mathrm{L}$ i/ili prokalcitonin $(\mathrm{PCT})>0,5 \mathrm{mg} / \mathrm{L}$. Katehol-O-metiltransferaza je analizirana poslijeoperacijski. Kriterije za postojanje sustavne upale imalo je $15(34,8 \%)$ bolesnika. Tramadol je značajno smanjio bol u odnosu na stanje prije primjene, neovisno o postojanju sustavne upale ( $<<0,05$ u svim mjerenjima). Bolesnici koji su imali sustavnu upalu imali su nižu percepciju boli prije primjene tramadola u odnosu na one koji nisu imali sustavnu upalu, no ova razlika nije bila statistički značajna. Statistički značajna negativna korelacija zabilježena je između prijeoperacijskih vrijednosti CRP-a i PCT-a i analgetskog učinka tramadola u drugoj mjernoj točki $(r=-0,358, p=0,03$ i $r=-0,364, p=0,02)$. Katehol-O-metiltransferaza nije povezana s potrošnjom analgetika niti jačinom boli. Rezultati ovog istraživanja pokazali su da je tramadol učinkovit u smanjenju boli nakon abdominalnih operacijskih zahvata neovisno o znakovima sustavne upale.

Ključne riječi: Analgezija; Intenzivno liječenje; Sustavni upalni odgovor; Katehol-O-metiltransferaza; Tramadol 